\section{Research Square}

Preprints are preliminary reports that have not undergone peer review.

They should not be considered conclusive, used to inform clinical practice, or referenced by the media as validated information.

\title{
Investigation on residents' cognition of HFRS and related knowledge in Jining city of Shandong Province, Mainland China
}

\author{
Miao-Miao Liu ( $\square$ miao1206@126.com ) \\ Jining Medical University \\ Wen-Jun Wang \\ Jining Medical University \\ Wen Liu \\ Zaozhuang Center for Disease Control and Prevention \\ Li-Yan Guo \\ Jining Medical University
}

\section{Research Article}

Keywords: HFRS, cognition, behavior

Posted Date: February 28th, 2022

DOl: https://doi.org/10.21203/rs.3.rs-1371840/v1

License: (c) (i) This work is licensed under a Creative Commons Attribution 4.0 International License. Read Full License 


\section{Abstract}

Background冈Hemorrhagic fever with renal syndrome (HFRS) is a serious public health problem caused by Hantavirus. China is the most severe endemic country in the world, accounting for about $90 \%$ cases. However, there are relatively few studies on residents' cognition of HFRS in the epidemic areas.

Methods: 960 residents were selected from four districts of Jining city, Shandong province in 2020. Information on cognition of HFRS and related knowledge was obtained using a questionnaire. Chi-square test was used to compare the differences of the cognition rate between demographic characteristics. The stepwise logistic regression analysis was used to determine the association between personal variables and cognition.

Results: The data from 892qualified questionnaires were analyzed. The result showed that the cognition rate of HFRS among residents in Jining is $50.00 \%$. The cognition rate of the source of HFRS infection among residents is $42.60 \%$. And the cognition rate of HFRS vaccine is only $17.71 \%$.Further regression analysis result showed that the main factors affecting residents' cognition of HFRS and related knowledge were age and education. Residents' awareness of infectious source affected their behavior. The results showed that $18.95 \%$ of the residents who knew the infectious source took protective measures when sweeping the barns, while among the residents who did not know the infectious source, only $10.16 \%$ of them took protective measures.

Conclusions: Residents' cognition of HFRS and related knowledge were affected by education. Residents' behavior would be affected by their cognition status.

\section{Introduction}

Hemorrhagic fever with renal syndrome (HFRS) is a global acute infectious disease caused by Hantavirus (HVs) in the Bunyaviridae family. The virus is transmitted mainly by rodent animals through urine, feces, and saliva and the aerosols produced by them. ${ }^{1}$ Clinical characteristics of HFRS include fever, hemorrhage, kidney damage, or even multiple organ dysfunctions. HFRS remains endemic in Asia and Europe, while increased incidence rate have been reported in China. ${ }^{2,3}$ The case fatality rate of HFRS reported in mainland China ranges from $1.13 \%$ to $1.31 \% .{ }^{3,4}$ Currently, there is no effective treatment available for HFRS. Despite HFRS bivalent inactivated vaccine and HFRS purified vaccine (Type I) are licensed for use in China, the protective efficacies of these vaccines are uncertain. ${ }^{5}$ Data from the National Notifiable Disease Surveillance System (NNDSS) shows that Shandong Province is one of the five provinces in China that has the highest incidence of HFRS ${ }^{6,7}$ The Chinese government attaches great importance to anti-HFRS programs, including rodent surveillance and control, public health education, environment management, and especially the free vaccination project in endemic areas. ${ }^{8}$ It is necessary to understand the disease cognition and behavior of residents in high epidemic areas of HFRS. In this paper, we analyzed the data of residents' cognition on HFRS and the vaccine. Furthermore, we investigated the behaviors of residents lived in the highendemic area. It would provide references for developing targeted strategies and measures on prevention of HFRS.

\section{Methods}

\section{Ethics approval and consent to participate}

Ethics Committee of Jining Medical University approved the investigation. The investigators ensured that each respondent fully understood the content of the study and volunteered to complete the survey.

\section{Site Selection and Subject Recruitment}

This investigation was based on an epidemiologic study in Jining City, Shandong province. Jining is located in the southwest of Shandong Province and includes 11 districts. Four districts were selected, including Jinxiang, Jiaxiang, Qufu, and Sishui. Three villages were randomly selected from each selected district, and 80 residents were investigated in each village. The survey was conducted with the informed consent of the participants. 
Cross-sectional information on disease cognition, knowledge of prevention vaccination, residential condition, and lifestyle was obtained through a questionnaire survey performed in 2020. All questionnaire responses were recorded electronically in a database according to a standardized code and file structure.

\section{Statistical analysis}

Statistical analysis was performed using IBM SPSS 22.0.Qualitative data were described by frequency. Chi-square test was used to compare the differences of the cognition rate between demographic characteristics. The stepwise logistic regression analysis was used to determine the association between personal variables and cognition. The results were considered to be significant at $p<0.05$.

\section{Results}

\section{Characteristics of the Participants}

Of the 960 eligible participants, 892 returned the questionnaire (92.92\%).The average age of the respondents was 56.37 and 524 of them were male. Participation rates varied across districts from 90.83 to $95.83 \%$, but there was no significant difference. There were no significant differences in demographic characteristics, such as gender, profession, education and household income among different districts (Table 1).

The awareness rate of HFRS in the four districts was $52.29 \%, 49.31 \%, 51.11 \%$ and $47.39 \%$, respectively, and there was no statistical difference $\left(c^{2}=1.24, p=0.74\right)$. The awareness rate of infectious source in the four districts was $39.91 \%, 42.01 \%, 43.11 \%$ and $43.48 \%$, respectively, and there was no statistical difference $\left(c^{2}=0.19, p=0.98\right)$. In addition, there was slight difference on the cognitive status of HFRS vaccine among the four districts, but the difference was not statistically significant (Table 2).

\section{Univariate analysis of cognitive status}

The awareness rate of HFRS of the investigated residents was $50.00 \%$. The residents who have these characteristics, such as male, migrant worker, younger age, higher education and higher income had higher awareness rate of HFRS. The awareness rate of infectious source was $42.60 \%$ which is lower than the cognition of HFRS. It was found that characteristics such as gender, profession, education level and age would have an impact on the awareness rate of infectious source of the residents. The residents' awareness rate of HFRS vaccine was $17.71 \%$. The residents with the characteristics, such as younger age and higher education had higher awareness rate of HFRS vaccine (Table 3).

\section{Multivariate analysis of cognitive status}

Table 4 presents multivariate relationship between the cognition and potentially relevant personal characteristics. As shown in table 4, age is a risk factor for the cognition of HFRS. Factors like education and family income were found to be associated with the cognition of HFRS. There was a similar pattern for cognition of infectious source, and female's awareness of infectious source was lower than the male. Education was the only factor associated with the cognition of vaccine. Compared to the residents with primary education, the residents who had higher education had higher cognition for vaccine $(0 \mathrm{R}=0.69,95 \% \mathrm{Cl}$, 0.56-0.84).

\section{The influence of infectious source cognition on residents' behavior}

We analyzed whether residents' behavior would be affected by their awareness of infectious source. The results showed that the effect did exist. Residents who knew rodent was the infectious source of HFRS tended to sweep barns more frequently $(41.05 \%$ VS $20.31 \%, p<0.01)$. Furthermore, when cleaning the barns whether the residents took personal protective measures was analyzed. The result indicated that $18.95 \%$ of the residents who knew that rodent were the infectious source took protective measures such as wearing a mask or gloves when sweeping the barns, while among the residents who did not know the 
knowledge, only $10.16 \%$ of them took protective measures. The difference was statistically significant. $57.37 \%$ of residents who knew the infectious source would adopt measures to prevent the grain from being contaminated by rodents. However, only $25.00 \%$ of residents who didn't know the source of infection took precautions. The result showed that the proportion of drinking unboiled water was $8.42 \%$ among the residents who knew the infectious source. It was lower than the residents who did not know that. Among the residents who knew the source of infection, $88.42 \%$ would bask the quilt more frequently which was statistically higher than the residents who did not know the knowledge (Table 5).

\section{Discussion}

HFRS which is caused by HVs is a seriously global threat for public health. Rodents, shrews, and moles are the reservoir animals for HVs. ${ }^{9}$ China is the most severe endemic country in the world, accounting for about $90 \%$ of human cases. ${ }^{10}$ The Chinese government paid great attention to the prevention and control of HFRS, including rodent surveillance and control, public health education, environment management, and especially the free vaccination project in high endemic areas. ${ }^{8}$ Nevertheless, this investigation found that the residents' cognitions on HFRS and the infectious source were worrying. Only $17.71 \%$ of respondents knew about HFRS vaccine. More worryingly, the HFRS vaccination rate of the respondents was $0.0 \%$. The reason may be that residents do not pay enough attention to vaccination. Several studies have shown a decline in vaccination willingness in China and the world. ${ }^{11,12}$ Furthermore, our research found that the cognition of the infectious source affected the residents' behaviors which have been proven to be helpful in preventing HFRS. ${ }^{13}$ It is gratifying that our survey showed that education was a favorable factor to improve residents' awareness of HFRS and relative knowledge. Similar to this study, a survey of U.S. adults indicated that people with a bachelor's degree or higher was significantly more likely to get COVID-19 vaccination. ${ }^{14} \mathrm{~A}$ systematic review indicated that interventions that delivered HPV-related education by authoritative sources and included parents improved HPV vaccination rates among adolescents and young adults. ${ }^{15}$ All the results suggested that, in the future, more attention should be paid to strengthen the publicity of HFRS prevention knowledge. The residents' awareness of protection should be improved, and good behaviors should be formed. And in particular, for the elderly farmers with low education level, pictures, videos and other vivid methods should be used for disease prevention publicity. Moreover, emphasis should be put on vaccine uptake. At present, the inactivated HFRS vaccines developed in China have been used in epidemic areas and have been proved to have good protective effects. ${ }^{13}$ It indicated that in endemic areas through community publicity to raise the vaccination rate would have a positive effect on the prevention of HFRS.

\section{Conclusion}

Our study demonstrated that education affected the residents' cognition of HFRS and related knowledge. Thus, more attention should be paid to promote residents' comprehensive health education in HFRS endemic areas.

\section{Declarations}

\section{Ethics approval and consent to participate}

Ethics Committee of Jining Medical University approved the investigation. The investigators ensured that each respondent fully understood the content of the study and volunteered to complete the survey.

\section{Consent for publication}

All authors read and approved the final manuscript.

\section{Availability of data and materials}

The datasets used and/or analyzed during the current study are available ;from the corresponding author on reasonable request.

\section{Competing interests}


All authors have declared there were no conflicts of interest to disclose.

\section{Funding}

This work was supported by A Project of Shandong Province Higher Educational Science and Technology Program (J18KA298) and NSFC cultivation project of Jining Medical University (JYP2018KJ11). The funder had no role in study design, data collection, and analysis, decision to publish, or preparation of the manuscript.

\section{Authors' contributions}

Questionnaire design and survey: Wang WJ, Liu MM; Data analysis: Liu MM, Liu W; Wrote the paper: Liu MM; Revised the paper: Guo LY.

\section{Acknowledgements}

Thanks to the staff of Nishan County Health Center for their support and cooperation.

\section{References}

1. Brocato RA-O, Hooper JW (2019) Progress on the Prevention and Treatment of Hantavirus Disease Viruses 11: 610.

2. Guo Q, Xu J, Shi Q, Du B (2021) Acute pancreatitis associated with hemorrhagic fever with renal syndrome: a cohort study of 346 patients. BMC Infect Dis 21: 267.

3. Huang X, Yin H, Yan L, Wang X, Wang S (2012) Epidemiologic characteristics of haemorrhagic fever with renal syndrome in Mainland China from 2006 to 2010. Western Pac Surveill Response J 3: 12-18.

4. Zhang S, Wang S, Yin W, Liang M, Li J, et al. (2014) Epidemic characteristics of hemorrhagic fever with renal syndrome in China, 2006-2012. BMC Infectious Diseases 14: 384.

5. Liu R, Ma H, Shu J, Zhang Q, Han M, et al. (2020) Vaccines and Therapeutics Against Hantaviruses. Front Microbiol 10 : 2989.

6. Chen JJ, Guo TC, Song SX, Shao ZJ, Liu K (2020) Epidemiological characteristics and the development of spatiotemporal analysis models on hemorrhagic fever with renal syndrome in China. Zhonghua Liu Xing Bing Xue Za Zhi 41: 1735-1740.

7. Zheng Z, Wang P, Wang Z, Zhang D, Wang X, et al. (2019) The characteristics of current natural foci of hemorrhagic fever with renal syndrome in Shandong Province, China, 2012-2015. PLoS Negl Trop Dis 13: e0007148.

8. Liu X, Zhang T, Xie C, Xie Y (2016) Changes of HFRS Incidence Caused by Vaccine Intervention in Yichun City, China, 20052013. Med Sci Monit 22: 295-301.

9. Ashique S, Sandhu NK, Das S, Haque SN, Koley K (2022) Global Comprehensive Outlook of Hantavirus Contagion on Humans: A Review. Infect Disord Drug Targets Online ahead of print.

10. Wu G, Xia Z, Wang F, Wu J, Cheng D, et al. (2020) Investigation on risk factors of haemorrhagic fever with renal syndrome (HFRS) in Xuancheng City in Anhui Province, Mainland China. Epidemiol Infect 148: e248.

11. Lv M, Fang R, Wu J, Pang X, Deng Y, et al. (2016) The free vaccination policy of influenza in Beijing, China: The vaccine coverage and its associated factors. Vaccine 34: 2135-2140.

12. de Figueiredo A, Johnston I, Smith DMD, Larson HJ, Jones N (2015) Changing socioeconomic determinants of childhood vaccines: a global analysis over three decades. Lancet Global Health 3: 20.

13. Wang X, Shen W, Qin Y, Ying L, Li H, et al. (2020) A case-control study on the risk factors for hemorrhagic fever with renal syndrome. BMC Infect Dis 20: 103.

14. Guidry JPD, Laestadius LI, Vraga EK, Miller CA, Perrin PB, et al. (2021) Willingness to get the COVID-19 vaccine with and without emergency use authorization. Am J Infect Control 49: 137-142.

15. Rani U, Darabaner E, Seserman M, Bednarczyk RA, Shaw J (2022) Public Education Interventions and Uptake of Human Papillomavirus Vaccine: A Systematic Review. J Public Health Manag Pract 28: E307-e315. 
Tables

Table 1. Demographic characteristics of the participants in different districts

\begin{tabular}{|c|c|c|c|c|c|c|c|}
\hline & & Jinxiang & Jiaxiang & Qufu & Sishui & $\begin{array}{l}\text { chi- } \\
\text { square }\end{array}$ & $P$ \\
\hline \multirow[t]{2}{*}{ Gender } & male & 122 & 134 & 127 & 141 & 2.35 & 0.5 \\
\hline & female & 96 & 85 & 98 & 89 & & \\
\hline \multirow[t]{3}{*}{ Profession } & farmer & 174 & 168 & 181 & 179 & 1.34 & 0.97 \\
\hline & migrant worker & 33 & 37 & 33 & 37 & & \\
\hline & unemployed & 11 & 14 & 11 & 14 & & \\
\hline \multirow[t]{3}{*}{ Age group } & $<40$ & 37 & 40 & 37 & 40 & 0.56 & 0.99 \\
\hline & $40 \sim$ & 90 & 88 & 96 & 92 & & \\
\hline & $60 \sim$ & 91 & 91 & 92 & 98 & & \\
\hline \multirow[t]{4}{*}{ Education } & primary school & 94 & 97 & 97 & 102 & 0.25 & 0.99 \\
\hline & junior high school & 99 & 98 & 102 & 103 & & \\
\hline & $\begin{array}{l}\text { technical secondary } \\
\text { school }\end{array}$ & 13 & 12 & 13 & 12 & & \\
\hline & high school and above & 12 & 12 & 13 & 13 & & \\
\hline \multirow{4}{*}{$\begin{array}{l}\text { annual household income per } \\
\text { capita }\end{array}$} & $<10,000$ & 79 & 68 & 83 & 76 & 2.57 & 0.98 \\
\hline & $10,000 \sim$ & 74 & 84 & 76 & 86 & & \\
\hline & $30,000 \sim$ & 46 & 47 & 47 & 48 & & \\
\hline & $50,000 \sim$ & 19 & 20 & 19 & 20 & & \\
\hline \multirow[t]{2}{*}{ Nationality } & Han & 216 & 215 & 224 & 225 & 3.25 & 0.36 \\
\hline & Others & 2 & 4 & 1 & 5 & & \\
\hline \multirow[t]{2}{*}{ Marital status } & married & 198 & 195 & 203 & 206 & 0.44 & 0.93 \\
\hline & others & 20 & 24 & 22 & 24 & & \\
\hline
\end{tabular}

Table 2. Cognitive status of HFRS and related knowledge in different districts

\begin{tabular}{llllllll} 
& & Jinxiang & Jiaxiang & Qufu & Sishui & chi-square & $P$ \\
\hline \multirow{2}{*}{ Cognition of HFRS } & Yes & 114 & 108 & 115 & 109 & 1.24 & 0.74 \\
\cline { 2 - 8 } & No & 104 & 111 & 110 & 121 & & \\
\hline \multirow{2}{*}{ Cognition of infectious source } & Yes & 91 & 92 & 97 & 100 & 0.19 & 0.98 \\
\cline { 2 - 8 } & No & 127 & 127 & 128 & 130 & & \\
\hline Cognition of the vaccine & Yes & 34 & 45 & 33 & 46 & 4.14 & 0.25 \\
\cline { 2 - 8 } & No & 184 & 174 & 192 & 184 & &
\end{tabular}

Table 3. Cognitions of HFRS and related knowledge of the Participants 


\begin{tabular}{|c|c|c|c|c|c|c|c|c|c|c|c|c|c|}
\hline & & \multicolumn{4}{|c|}{ Cognition of HFRS } & \multicolumn{4}{|c|}{$\begin{array}{l}\text { Cognition of infectious } \\
\text { source }\end{array}$} & \multicolumn{4}{|c|}{ Cognition of the vaccine } \\
\hline & & Yes & No & $x^{2}$ & $P$ & Yes & No & $x^{2}$ & $P$ & Yes & No & $x^{2}$ & $P$ \\
\hline \multirow[t]{2}{*}{ Gender } & male & 278 & 246 & 4.74 & \multirow[t]{2}{*}{0.03} & 252 & 272 & 15.66 & \multirow[t]{2}{*}{$<0.01$} & 98 & 426 & 0.85 & 0.36 \\
\hline & female & 168 & 200 & & & 128 & 240 & & & 60 & 308 & & \\
\hline \multirow[t]{3}{*}{ Profession } & farmer & 330 & 372 & 19.69 & \multirow[t]{3}{*}{$<0.01$} & 290 & 412 & 8.80 & 0.01 & 118 & 584 & 5.66 & 0.06 \\
\hline & $\begin{array}{l}\text { migrant } \\
\text { worker }\end{array}$ & 94 & 46 & & & 74 & 66 & & & 34 & 106 & & \\
\hline & unemployed & 22 & 28 & & & 16 & 34 & & & 6 & 44 & & \\
\hline \multirow[t]{3}{*}{ Age group } & $<40$ & 94 & 60 & 23.10 & \multirow[t]{3}{*}{$<0.01$} & 74 & 80 & 45.65 & \multirow[t]{3}{*}{$<0.01$} & 34 & 120 & 10.26 & 0.01 \\
\hline & $40 \sim$ & 200 & 166 & & & 196 & 170 & & & 76 & 290 & & \\
\hline & $60 \sim$ & 152 & 220 & & & 110 & 262 & & & 48 & 324 & & \\
\hline \multirow[t]{4}{*}{ Education } & $\begin{array}{l}\text { primary } \\
\text { school }\end{array}$ & 146 & 244 & 53.54 & \multirow[t]{4}{*}{$<0.01$} & 116 & 274 & 55.46 & \multirow[t]{4}{*}{$<0.01$} & 44 & 346 & 22.18 & \multirow[t]{4}{*}{$<0.01$} \\
\hline & $\begin{array}{l}\text { junior high } \\
\text { school }\end{array}$ & 234 & 168 & & & 202 & 200 & & & 92 & 310 & & \\
\hline & $\begin{array}{l}\text { technical } \\
\text { secondary } \\
\text { school }\end{array}$ & 40 & 10 & & & 36 & 14 & & & 8 & 42 & & \\
\hline & $\begin{array}{l}\text { high school } \\
\text { and above }\end{array}$ & 26 & 24 & & & 26 & 24 & & & 14 & 36 & & \\
\hline \multirow{4}{*}{$\begin{array}{l}\text { Annual } \\
\text { household } \\
\text { income } \\
\text { per capita }\end{array}$} & $<10,000$ & 118 & 188 & 26.79 & \multirow[t]{4}{*}{$<0.01$} & 104 & 202 & 21.33 & \multirow[t]{4}{*}{$<0.01$} & 54 & 252 & 0.69 & 0.88 \\
\hline & $10,000 \sim$ & 172 & 148 & & & 160 & 160 & & & 62 & 258 & & \\
\hline & $30,000 \sim$ & 114 & 74 & & & 90 & 98 & & & 38 & 150 & & \\
\hline & $50,000 \sim$ & 42 & 36 & & & 26 & 52 & & & 16 & 62 & & \\
\hline \multirow[t]{2}{*}{ Nationality } & Han & 442 & 440 & 0.41 & \multirow[t]{2}{*}{0.53} & 376 & 506 & 0.03 & 0.87 & 158 & 724 & 1.12 & 0.29 \\
\hline & Others & 4 & 6 & & & 4 & 6 & & & 0 & 10 & & \\
\hline \multirow{2}{*}{$\begin{array}{l}\text { Marital } \\
\text { status }\end{array}$} & married & 402 & 400 & 0.05 & \multirow[t]{2}{*}{0.82} & 332 & 470 & 0.92 & 0.34 & 142 & 660 & 0.00 & 0.99 \\
\hline & others & 44 & 46 & & & 42 & 48 & & & 16 & 74 & & \\
\hline
\end{tabular}

Table 4. Multivariate analysis of cognitive status 


\begin{tabular}{|c|c|c|c|c|c|c|c|c|c|}
\hline & \multicolumn{3}{|c|}{ Cognition of HFRS } & \multicolumn{3}{|c|}{$\begin{array}{l}\text { Cognition of the infectious } \\
\text { source }\end{array}$} & \multicolumn{3}{|c|}{$\begin{array}{l}\text { Cognition of the } \\
\text { vaccine }\end{array}$} \\
\hline & $B$ & OR & $95 \% \mathrm{Cl}$ & $B$ & OR & $95 \% \mathrm{Cl}$ & $B$ & OR & $95 \% \mathrm{Cl}$ \\
\hline Constant & 0.45 & प & प & 0.02 & प & प & 2.22 & ૫ & प \\
\hline Gender(ref: male) & ૫ & ? & प & 0.38 & 1.46 & $1.10-1.95$ & ૫ & ૫ & ? \\
\hline Age group(ref: <40) & 0.25 & 1.29 & $\begin{array}{l}1.05- \\
1.57\end{array}$ & 0.37 & 1.46 & $1.19-1.79$ & प & ૫ & प \\
\hline Education (ref: primary) & -0.34 & 0.71 & $\begin{array}{l}0.59- \\
0.86\end{array}$ & -0.45 & 0.64 & $0.53-0.78$ & -0.38 & 0.69 & $\begin{array}{l}0.56- \\
0.84\end{array}$ \\
\hline $\begin{array}{l}\text { Family income per capita(ref: } \\
<10,000)\end{array}$ & -0.21 & 0.81 & $\begin{array}{l}0.70- \\
0.94\end{array}$ & प & ૫ & ૫ & ૫ & ૫ & ૫ \\
\hline
\end{tabular}

Table 5. The influence of residents' cognition of infectious source on residents' behavior

\begin{tabular}{|c|c|c|c|c|c|}
\hline & & \multicolumn{4}{|c|}{ Cognition of the infectious source } \\
\hline & & Yes & No & $x^{2}$ & $P$ \\
\hline \multirow[t]{2}{*}{ sweep the barn } & Yes & 156 & 104 & 45.43 & $<0.01$ \\
\hline & No & 224 & 408 & & \\
\hline \multirow[t]{2}{*}{ personal protections } & Yes & 72 & 52 & 14.08 & $<0.01$ \\
\hline & No & 308 & 460 & & \\
\hline \multirow[t]{2}{*}{ preventive measures against rats } & Yes & 218 & 128 & 96.25 & $<0.01$ \\
\hline & No & 162 & 384 & & \\
\hline \multirow[t]{2}{*}{ unboiled water } & Yes & 32 & 50 & 0.47 & 0.49 \\
\hline & No & 348 & 462 & & \\
\hline \multirow[t]{2}{*}{ bask the quilt } & Yes & 336 & 402 & 14.98 & $<0.01$ \\
\hline & No & 44 & 110 & & \\
\hline
\end{tabular}

